\title{
Can biomass be satisfactorily gasified under pressure using an aqueous slurry feed? Examination by simulation
}

\author{
Brian Stanmore ${ }^{\mathrm{a}}$, Ange Nzihou ${ }^{\mathrm{b}, *}$ \\ a Formerly of the University of Queensland, Brisbane, QLD 4072, Australia \\ ${ }^{\mathrm{b}}$ Université de Toulouse, Mines Albi, CNRS, Centre RAPSODEE, Campus Jarlard, F-81013 Albi Cedex 09, France
}

\section{A B S T R A C T}

A major hurdle for the gasification of biomass under pressure is the need to introduce a fibrous biomass feed material such as straw, switchgrass or miscanthus into a pressure vessel. One proposed solution is to prepare a dense aqueous slurry from the biomass and then use a conventional high pressure pump. The production of syngas from wheat straw and subsequent power generation is examined theoretically in an Australian context. A slurry of concentration of $50 \%$ biomass by volume, which is regarded as the maximum pumpable value, is dried with superheated steam and the biomass gasified at $2 \mathrm{MPa}$ with steam only in cyclones. It was found that the thermal deficiency of introducing excessive liquid water is considerable, rendering the process unsustainable. The problem can be overcome by employing a subsidiary fuel such as natural gas, but even with the minimal amount of water, the required energy input is equivalent to that of the straw. The net electrical efficiency of the process based on both fuels is $33.5 \%$, so that the approach would be contemplated only if the over-riding consideration was the use of the straw for energy generation. The zero net present value cost of power production is $125 \$ \mathrm{MWh}-1$ for $90 \mathrm{Gg}$ of straw consumption per annum.

\section{Introduction}

The production of energy from biomass using thermal processes may follow the combustion, pyrolysis or gasification routes. Combustion is directed towards heat and electricity generation, while pyrolysis is employed for the production of liquid fuels. Gasification can satisfy either aim, but at the cost of greater process complexity and uncertainty. In the Australian context the process aims are generally less ambitious, and are confined to power generation. A preliminary study by the authors on the relative merits for power generation of combustion and gasification, both at atmospheric and elevated pressures, was undertaken [1]. The conclusion arrived at was that combustion is currently the only viable option, although pressure gasification is theoretically superior in terms of efficiency and cost.

The benefits of gasifying under elevated pressures rather than at atmospheric conditions have been repeatedly demonstrated e.g Bridgewater [2]. The process for carbonaceous fuels is more efficient when operated under a pressurised environment, with $2 \mathrm{MPa}$

\footnotetext{
* Corresponding author

E-mail address: ange.nzihou@mines-albi.fr (A. Nzihou).
}

a typical figure. The advantage for power generation is that this shifts the equilibrium composition towards higher concentrations of hydrocarbons (methane) and hence higher syngas specific energy, but at the expense of somewhat diminishing amounts of hydrogen and carbon monoxide [3]. The configuration does not require energy to pressurise the syngas for subsequent combustion in a gas turbine. In addition the process density is enhanced, with comparatively smaller reaction vessels required.

In the previous paper [1] an economic analysis was carried out which showed that pressurised gasification should be a better option than combustion for electricity generation, as the overall efficiencies of the former are far higher, and the cost to generate power is lower. Unfortunately, there are some technical challenges which are still unresolved. The clean-up of the syngas to make it suitable for further processing is the study of considerable research, which is slowly developing solution $[4,5]$. The major hurdle is the need to introduce a cohesive and/or fibrous biomass feed material such as straw, switchgrass or miscanthus into a pressure vessel.

One feeding option which has been proposed is to pulverise the fuel, make it into a dense slurry, and pump it into the gasifier using conventional pumps. A literature search has not uncovered many examples of slurry feeding using water, which would be technically 
the simplest. More emphasis has been placed on bio-oil produced by pyrolysis as the slurry medium. The gasification of this oil and the corresponding char has received some attention e.g. Refs. [6-9].

The process of producing a dense slurry of biomass involves a number of difficult steps. Most biomass is hard to handle and resists pulverisation to fine sizes. Dry materials will retain their inherent cell structures (see Fig. 1), which on water addition will be filled before free water will become available to mobilise the particle assembly. The only way to minimise overall slurry water content is to pulverise the biomass to a sufficiently small size which ensures destruction of the major cell walls.

The consequence of this is that a slurry produced from even a dry feed material will contain quantities of water which compromise the thermal conditions of a gasifier. In a conventional system air (or oxygen) is added in sufficient quantity to maintain the operating temperature at the required value, typically in the vicinity of $800^{\circ} \mathrm{C}$. The presence of water lowers the efficiency to such an extent that pre-drying is essential, which then transfers the thermal penalty to this operation. It must be addressed by adopting a suitable process configuration, typically with integration of the various steps.

For example, the most prominent proponent of aqueous slurry feeding is de Souza-Santos, who with co-workers has published a series of detailed papers, of which the latest are [10-13]. At this stage, they are desk-top studies which examine a similar concept with different conditions and fuels. The last of the series, which considers operation at a very high pressure to produce a net mechanical output of $\sim 106 \mathrm{MW}$ [12], will be examined as typical of the approach.

The fuel considered is a hypothetical biomass with $50 \%$ asreceived moisture and a comparatively large particle size $(82 \%>1.68 \mathrm{~mm})$. This feed is slurried with water, pumped, dried in a fluidised bed at $10 \mathrm{MPa}$ using flue gas from a gas turbine, and the dry solid then passed to a fluidised bed gasifier operating at a similar pressure.

There are a number of assumptions in the proposal which need closer examination. The core of the process is the production of an aqueous slurry containing $40 \%$ solid biomass by weight. The $60 \%$ of water is comprised of $40 \%$ inherent in the biomass and an extra $20 \%$ of added free water. Since the particles are comparatively large, the cellular plant structures would remain, and retain the inherent water. The added water does not appear to offer enough volume to fill interstices such that the particles would be mobilised. On a volume basis assuming the inherent water is retained, the slurry is likely to be $80 \%$ solids. The feed system would then be more of an extrusion rather than a pumping operation. The authors nominate a manufacturer who would supply such a device, which needs to be confirmed in practice. The complicated flowsheet incorporates two gas turbines, five steam turbines and three gas compressors, all of the latter with an intercooling stage.

It is hard to regard the process as practical when it relies on such an arrangement. For instance, when considering the steam turbines, the mechanical outputs range from lows of $0.7,3,15$ and $25 \mathrm{MW}$ up to $104 \mathrm{MW}$. Of the gas turbines, one has an output of $222 \mathrm{MW}$, and the other $25 \mathrm{MW}$ during which the working gas decreases in entropy. The larger turbine operates at 9.9 MPa, which is beyond the range of conventional machines.

A major flaw in all the processes is the venting direct to the atmosphere of large quantities of wet gas from the driers at high pressures e.g. $83 \mathrm{~kg} \mathrm{~s}^{-1}$ at $0.9 \mathrm{MPa}$ [12], $70 \mathrm{~kg} \mathrm{~s}^{-1}$ at $2.2 \mathrm{MPa}$ [11]. This is inconceivable. The other configurations detailed in companion papers suffer from similar defects, meaning that the plants described are unrealistic in concept.

In the present simulation, an assumption has been made that the amount of water required for such a process will be determined by slurry rheology. As a consequence the principal disadvantage of this method is the large quantity of water introduced, and the subsequent need to dry the biomass before the gasification reaction. Application of the simulation software used here quickly revealed that the water deemed necessary to produce a slurry made the system unfeasible. As a result a supplementary fuel, in this case natural gas, was required to support the drying/gasification reaction. The quantity of NG was varied until a satisfactory energy balance was obtained. It was found to be roughly equivalent, in energy terms, to the amount of straw processed.

This paper proposes the use of superheated steam, rather than air as the drying agent, and then employing the generated steam as the only gasifying medium. It also proposes the use of a pressurised cyclone as the gasifier, thus simplifying the operation of pressure vessels.

The advantages of this system are as follows.

- Conventional feeding equipment is employed.

- The steam drying process is equally as efficient as, or more efficient than with air.

- High energy syngas is generated as nitrogen is excluded from the gasifier.

- The cyclone can act as an efficient, compact gas-solid contacting reactor.

The simulation is applied to wheat straw from central Western Australia, one of the major cereal-producing regions of the world.
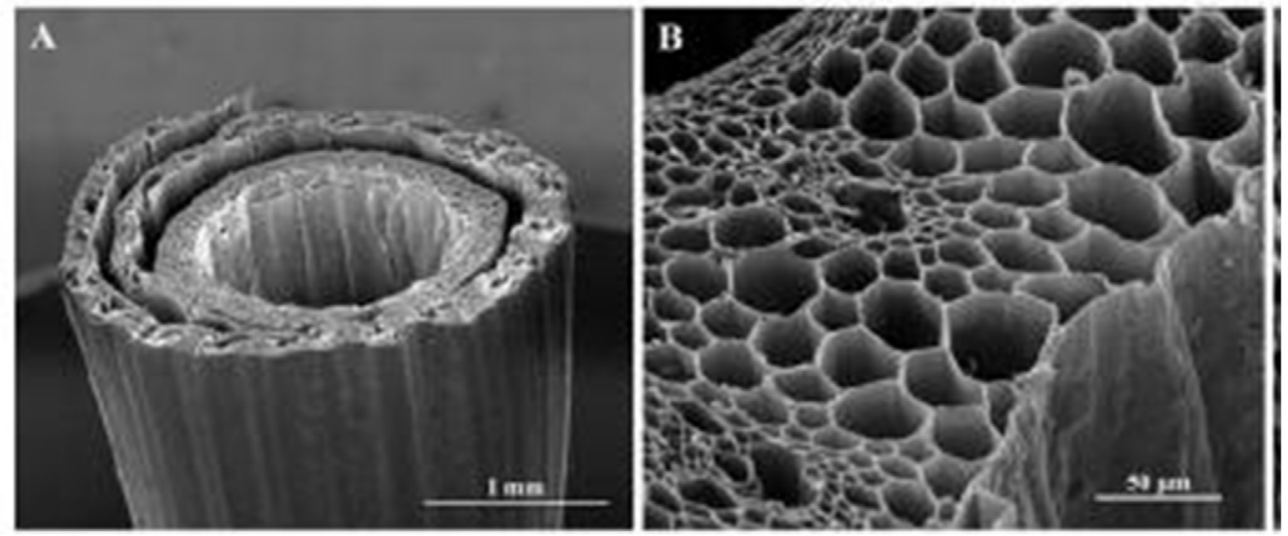

Fig. 1. Micrographs of a stalk of straw [22]. 
This choice was made because considerable amounts of feedstock are available, and a study of availability and cost is available in the literature [14].

\section{Procedure}

\subsection{Process configuration}

Since the feed will be presented to the high temperature process vessels as a liquid, it was decided to use a continuous-flow system for drying and gasifying. This has advantages for heat transfer and the cost of pressure vessels.

The core of the process is an assembly of cyclones which is fed at the operating pressure with a mixture of steam and the biomass. The steam is supplied both by externally superheated steam, and by the water from a dense biomass slurry. The cyclones are arranged in a closely-packed configuration to produce the required reaction surface area for the biomass particles as they pass through the system. By alternating the lines of feed pipes, a compact design of multiple rows of cyclones can be designed to fit into a gas-fired chamber. They are externally heated by a natural gas flame to maintain the chosen operating temperature. The emerging fluegas is then used to supply heat for the evaporation of the water in the slurry before it enters the cyclones. A battery of parallel gasification assemblies is required to give a commercial throughput.

A suitable arrangement of one gasifier assembly is shown in Fig. 2. The process involves first shredding and then wet grinding the straw feed in a ball mill, followed by preparing it as a dense slurry in an agitated tank. A diaphragm pump then supplies the slurry to an array of tubular risers with rifled bores, modulated through a control valve. Rings of manifolds feed superheated steam

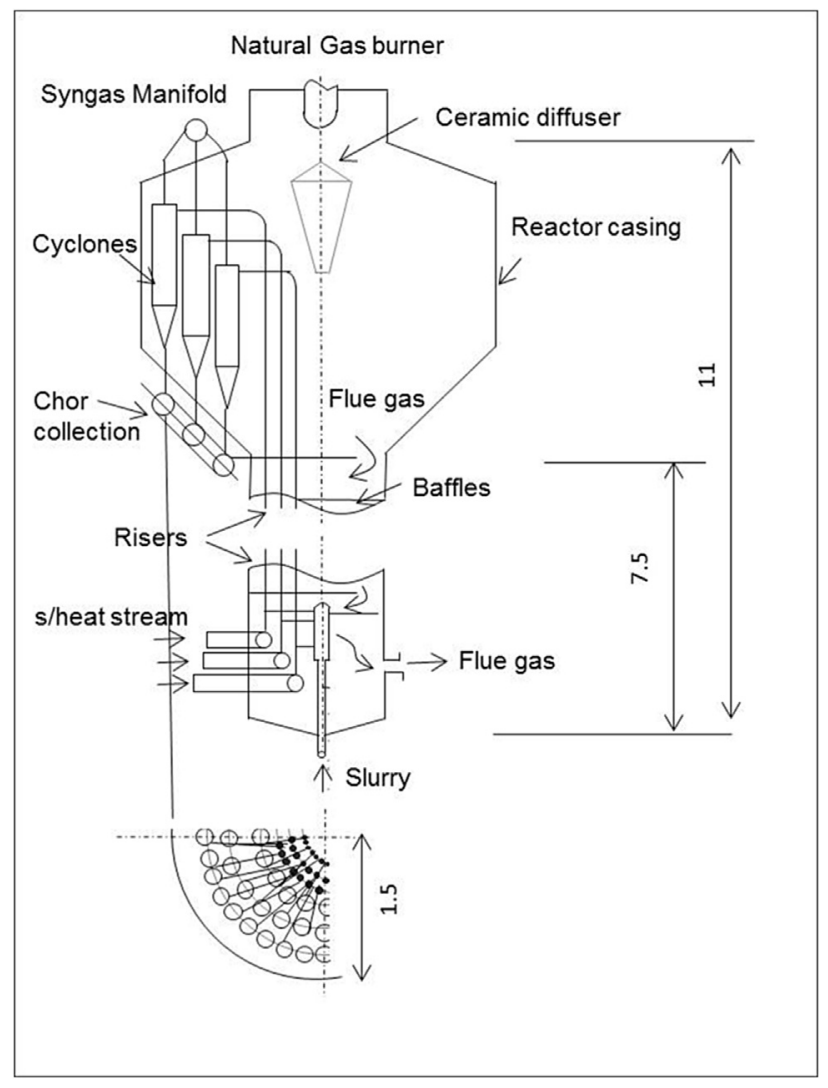

Fig. 2. Elevation of proposed cyclone gasifier. into the bottom of the risers, entraining the slurry on the way. The water in the mixture is evaporated as it traverses the riser, and then empties into the cyclones, where the gasification process is completed. The syngas is collected in a manifold and forwarded to the heat extraction exchangers.

The cyclones are maintained at a temperature of $800{ }^{\circ} \mathrm{C}$ by means of a natural gas flame firing into a chamber surrounding the cyclones. Char and ash are extracted from the bottom outlet of the cyclones, from where they pass to a manifold and are collected in a lock hopper. The off-gas from the natural gas flame is subsequently directed into the vertical cylindrical casing enclosing the riser bundle, which is configured with shell-side baffles like a shell-andtube exchanger. Thus further heat is extracted from the fluegas to support the drying process. The fluegas is then used to preheat the biomass slurry to $210{ }^{\circ} \mathrm{C}$ in another external exchanger before passing to the stack.

The flowchart of the proposed process, which is shown in Fig. 3, is fairly conventional BIGCC technology. The inputs and outputs parameters are presented in Table 3. The steam cycle is specified as $6 \mathrm{MPa}$ at $460{ }^{\circ} \mathrm{C}$, with a final condensing pressure of $20 \mathrm{kPa}$ absolute at a temperature of $60{ }^{\circ} \mathrm{C}$. The gasifying medium is steam taken from the extraction turbine at $2.2 \mathrm{MPa}$, and then reheated to $650{ }^{\circ} \mathrm{C}$; it represents $17 \%$ of the steam flow entering the turbine.

The gas turbine is envisaged as a utility machine such as a GE MS-6101FA unit [15] which has a pressure ratio of 14.9 and a maximum flame temperature of $1280{ }^{\circ} \mathrm{C}$. The syngas emerging from the cyclone battery is used to superheat the steam extracted from the turbine of the steam cycle. This cools it to $360^{\circ} \mathrm{C}$, which is beneath the alkali condensing temperature necessary for the gas cleaning step. The final stack temperature is $138^{\circ} \mathrm{C}$.

\subsection{Dense slurries}

Maintaining a minimum of water in the feed is crucial to successful operation of an auto-thermal gasifier, but it is difficult to prepare dense slurries of biomass because of the latter's porous nature. For instance, when an equal quantity by mass of water was added to some wheat straw, no free water remained present [16]. Lignocellulosic material intended for biological treatment is generally pre-treated with acid to improve slurry preparation e.g. Refs. [16-18]. In the latter case even a $30 \%$ by mass slurry of acidified corn stover returned apparent shear stresses around $45 \mathrm{kPa}$. Yield stresses of this order are reported for $50 \%$ by volume slurries of non-porous nylon fibers [19], and the shear stress rises to the third power of the volume fraction.

Dense slurries are generally characterised by the volume fraction of the solid in suspension. The literature indicates $[20,21]$ that a $50 \%$ volume fraction mixture is about the maximum possible loading which will give a mobile slurry able to be pumped by a standard high pressure pump. Unfortunately biomass such as 'grassy' wheat straw retains the plant cell structure, which involves the cellulosic cell walls surrounding what is effectively a void space where the cytoplasm has consolidated by drying after ripening. An example is shown in Fig. 1, where two scales of voidage are apparent [22]. Without pulverisation, this voidage would enclose water which will not contribute to the interstitial fluid mobilising the slurry.

It follows that the finer the grinding of the straw, the higher will be the particle density, and the denser the slurry which can be produced. Following a program of measurement, Lam et al. [23] report the following "Assuming that a particle is a solid cylinder, the bulk density of wheat straw was about $90 \mathrm{~kg} \mathrm{~m}^{-3}$, assuming it was a hollow cylinder the bulk density was $500 \mathrm{~kg} \mathrm{~m}^{-3}$, and measuring the volume using a pycnometer, the particle density was roughly $1100 \mathrm{~kg} \mathrm{~m}^{-3}$." Accordingly the particle density of finely- 


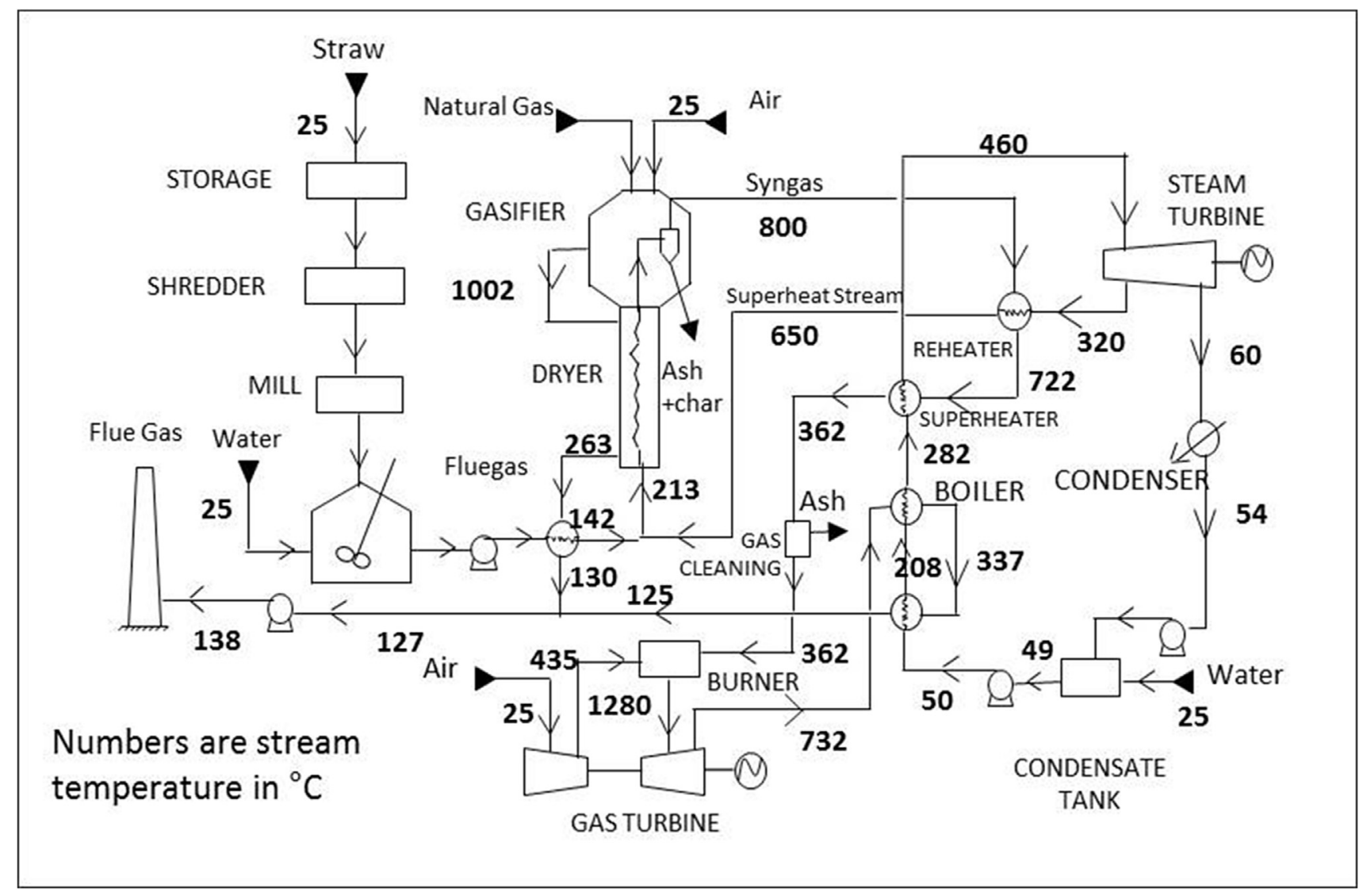

Fig. 3. Flow diagram for the gasifier.

divided straw was taken as $700 \mathrm{~kg} \mathrm{~m}^{-3}$, which implies the retention of some voidage.

To obtain a $50 \%$ slurry by volume, the mass fraction of straw is $41 \%$, with $59 \%$ water. Slurry of this concentration can be produced by careful preparation [24-26] and flow modifiers could be added to enhance wetting and fluidity. One specification for particle size distribution often cited for fuel applications [27] is that $75-80 \%$ of the particles must be less than $75 \mu \mathrm{m}$, which reflects the desired sizing for pulverised coal firing. The effect of particle size on slurry behavior is illustrated by Chen et al. [21], who found that a wider distribution is effective in lowering viscosity at the same solid loading. By examining Fig. 1 micrograph of Kristensen et al. [22], it appears that the straw needs to be reduced to $<120 \mu \mathrm{m}$ size by pulverisation to open up some of the finer cell structures.

\subsection{Superheated steam drying}

Stahl et al. [28] quote Mujumdar [29] concerning the advantages of superheated steam dryers over air dryers. No oxidation or combustion reactions are possible. Steam dryers have higher drying rates than air and gas dryers. Steam drying also avoids the danger of fire or explosions and allows toxic or valuable liquids to be separated in condensers.

The use of steam drying has been recorded for a range of applications, particularly for low rank coals e.g. Ref. [30]. A comparison of the effects of air, microwave and superheated steam drying found that there was little difference between the processes [31]. They found that during steam drying, aromatic structures remained relatively unchanged up to $250{ }^{\circ} \mathrm{C}$, but decreased significantly thereafter because of some pyrolysis reactions that took place at higher drying temperatures. Carboxyl and carbonyl groups were especially labile. Steam drying experiments under elevated pressure showed that the rate of drying is limited by the rate of external convective heat transfer [32].

The operating pressure appears to have no influence on the drying rate [32]. The equilibrium moisture content is higher in a higher pressure steam, and this equilibrium is attained earlier. At atmospheric pressure and ambient temperature, the equilibrium moisture content rises from $8 \%$ at $50 \% \mathrm{RH}$ to $30 \%$ at $90 \%$ saturation [33]. At $2 \mathrm{MPa}$ and $300{ }^{\circ} \mathrm{C}$, it was assumed that the equilibrium moisture content was effectively zero [34]. The turbulent nature of the steam/slurry flow means that drying of the fine straw particles would be almost instantaneous.

One application of steam drying applied to biomass involves sawdust in a spouted bed at 200 or $240{ }^{\circ} \mathrm{C}$ [35], and other trials have been carried with the steam gasification of biomass chars [36-39]. Higher temperatures were considered here, so that some biomass decomposition can be anticipated. Biomass pyrolysis commences when the temperature approaches $300{ }^{\circ} \mathrm{C}[40]$, beginning with hemicellulose, followed by cellulose and finally lignin. The changes under torrefaction with an inert atmosphere reflect this behavior [41-43]. Any decomposition of the straw in the technology proposed here will not affect the overall result, as all vapour products will undergo reaction in the riser and cyclone.

\subsection{Cyclone reactor technology}

In a series of papers Lédé and co-workers [44-47] have shown 
that the cyclone is capable of performing as a high-throughput pyrolysis or gasification reactor. The reaction and product separation actions are incorporated into the same vessel. The capacity of the cyclone to achieve high conversion rates for the solids is put down by Lédé [44] to ablative reaction i.e. the heat transfer and chemical reactions are much faster than heat conduction through the solid. The reactions occur in a thin layer at the surface, and steep temperature gradients are formed. It was found experimentally that there was a reproducible upper limit to throughput, above which the sawdust being gasified adhered to the walls and blocked the flow.

The gasification of rice husks was successfully achieved in a cyclone reactor using air as the gasifying medium [48]. It was found that judiciously introducing some of the air as a secondary stream improved the quality of the syngas. The throughput achieved was similar to that found by Lédé. Gabra et al. [49] also employed cyclones when gasifying bagasse.

\subsection{Process modelling}

The analysis used for the straw, which is taken from Saidur [50], gives $8 \%$ moisture and $12 \%$ ash, and is presented in Table 1. In view of the results found from our previous paper, a feedrate of $3.26 \mathrm{~kg} \mathrm{~s}^{-1}$ of as-fired straw was modelled, which produces about $10 \mathrm{MW}$ of electrical power in a combustion system and $15 \mathrm{MW}_{\mathrm{e}}$ under pressurised gasification. This feed rate is equivalent to about $90 \mathrm{Gg}$ annum-1. In that study, the process design and economic analysis were carried out by means of the ECLIPSE software. ECLIPSE was developed at the University of Ulster specifically for such energy-based applications [51,52], and is used again here.

The ECLIPSE software is divided into a sequential series of steps which entail (1) building a process flowsheet, (2) entering feed data, (3) carrying out a material and energy balance, (4) calculating the utility requirements, (5) estimating the process and utilities capital costs, (6) adding process stream and fuel costs, and finally (7) performing an economic analysis. There is a data base supplied for reaction components which can be supplemented by the user, and a file base for process equipment design and costs. The system is run manually on an iterative basis until all defined input and output values are satisfied.

When it was apparent that a supplementary fuel was necessary, a sequence of simulations was progressively carried out with natural gas introduced through a burner firing into the gasifier enclosure, until the operating temperature could be maintained at $800{ }^{\circ} \mathrm{C}$. This is the figure reported in the results.

For the present design, a fuel stock of 21 day's supply on-site was deemed appropriate. With straw bales or rolls averaging only $180 \mathrm{~kg} \mathrm{~m}^{-3}$ in density, large covered storage areas are required. The bales are shredded with a hammer-mill and the slurry prepared by wet grinding in a ball mill fitted with a classifier circuit. Since this is at the heart of the process, it is one aspect which would need careful attention. Obtaining a suitable particle size distribution to satisfy both the pumping and drying/reaction requirements would be crucial to a successful operation.

The gasification reaction was assumed to be carried out at $800{ }^{\circ} \mathrm{C}$, which ensures sufficiently high reaction rates and minimises downstream problems. The tars formed at lower

Table 1

Straw analysis.

\begin{tabular}{ll}
\hline Moisture content (as-sampled) \% & 8 \\
Ash mass fraction (dry basis \%) & 12 \\
Ultimate analysis (daf) \% mass & C 49.6, H 5.3, N 0.8, S 0.1, O 44.2 \\
HHV (daf) MJ kg & 17.7 \\
\hline
\end{tabular}

temperatures tend to be smaller molecules which are more easily processed in the gas clean-up step.

The number of cyclones to be employed is determined by their maximum capacity, identified by Lédé as $9 \mathrm{~g} \mathrm{~s}^{-1}$ per square metre of cyclone heated wall area [45]. The load under consideration therefore requires $360 \mathrm{~m}^{2}$ of wall area. Cyclones of $200 \mathrm{~mm}$ internal diameter are employed, with the length of the parallel body extended to one metre (following [48]) to increase the wall area. Each provides $0.78 \mathrm{~m}^{2}$ of heated area, so that approximately 460 cyclones are necessary. Allowing for a cyclone wall thickness of $10 \mathrm{~mm}$, the design shown in Fig. 2 accommodates a maximum of 85 such cyclones, meaning that 6 units would suffice.

A standard cyclone of this size requires an inlet pipe of rectangular cross-section of $50 \times 100 \mathrm{~mm}$, and has a $\mathrm{d}_{50}$ cut size of $<10 \mu \mathrm{m}$ [53]. However, the gas entry velocity for cyclones should be $10-15 \mathrm{~m} \mathrm{~s}-1$, which sets the preferred inlet pipe dimensions. An inlet aperture of $200 \mathrm{~mm}^{2}(10 \times 20 \mathrm{~mm})$ will produce a velocity of $10-11 \mathrm{~m} \mathrm{~s}^{-1}$ under the conditions envisaged.

The evaporation/drying rate under steam is controlled by heat transfer considerations, so that the height of the risers is determined by that rate. Boiling heat transfer rates in water-wall boiler tubes under radiant conditions can sustain $400 \mathrm{~kW} \mathrm{~m}^{-2}$; in this case the transfer will be controlled by the outside convective conditions, with an overall coefficient taken as $200 \mathrm{~W} \mathrm{~m}^{-2} \mathrm{~K}^{-1}$. By choosing an inside tube diameter appropriate to the cyclone inlet of $12.5 \mathrm{~mm}$, the evaporation is complete in $7.5 \mathrm{~m}$ of tube. Further drying will take place in the approach section of the cyclones.

The slurry is preheated to $200{ }^{\circ} \mathrm{C}$ before passing to the dryer, where the temperature is progressively raised to $800^{\circ} \mathrm{C}$, vaporising all water in the process. This implies that the pyrolysis reactions would be initiated before char gasification, which is preferable for low tar formation and efficient char gasification [54]. It was assumed that the gasifying/drying steam would be reheated to $650{ }^{\circ} \mathrm{C}$, and be fed to the bottom of the riser at $40 \%$ of the rate of water added to produce the preheated slurry. This ensures that there will always water present as vapour in the drying phase. The steam: carbon mol ratio is 3.7:1 in the dryer and gasifier.

As a complete thermodynamic or kinetic evaluation of the gasification process is not available in ECLIPSE, some assumptions are required. Because the biomass feed is present in fine sizes, and almost total conversion of wood powder in ablative cyclone reactors was observed $[45,46]$, the gasification reaction was assumed to be essentially complete. In addition, a solution requires some user input. For example, the extent of char formation and of methane formation needed to be specified, which was carried out based on literature values [52]. As only one equilibrium calculation could be included, the water gas shift reaction was chosen: $\mathrm{CO}+\mathrm{H}_{2} \mathrm{O} \leftrightarrow \mathrm{CO}_{2}+\mathrm{H}_{2}$

Most examinations of gasification product systems conclude that the gases leave the gasifier at close to equilibrium conditions e.g. Refs. [55,56]. It can be seen that this reaction is insensitive to pressure, whereas hydrocarbon formation is favoured by higher pressures. The assumed/predicted output gas composition is shown in Table 2, together with experimental outputs from other steambased gasification trials of biomass [36,37,39], as well as an equilibrium value for a 3:1 steam:carbon ratio [3].

Tar formation is a major concern in gasification operations. There is evidence that gasification with excess steam will significantly reduce the quantity of tars formed at $800^{\circ} \mathrm{C}$ [57], perhaps to a level of a few percent of the feed biomass [58]. Lignin gives a higher tar yield than cellulose or hemi-cellulose, and produces more stable components in tar due to its molecular structure [59] but wheat straw is in the lower range of lignin contents for biomass $[22,50]$. For these reasons it was assumed that a conventional tar removal system would perform adequately. 
Table 2

Composition of dry synthesis gas from steam gasification (volume \%).

\begin{tabular}{|c|c|c|c|c|c|c|}
\hline Author [Ref] & Pressure (MPa) & $\mathrm{CH}_{4}$ & $\mathrm{CO}$ & $\mathrm{CO}_{2}$ & $\mathrm{H}_{2}$ & $\mathrm{HHV}$ (dry) (MJ m $\left.{ }^{-3}\right)$ \\
\hline This work & 2 & 6.4 & 15.8 & 24.0 & 53.7 & 10.8 \\
\hline [36] & 0.1 & $2-9$ & $12-17$ & $24-27$ & $50-56$ & $\sim 11$ \\
\hline [37] & 0.1 & 6 & 22 & 27 & 38 & 10.1 \\
\hline [38] & 0.1 & 7 & 20 & 17 & 50 & 9.5 \\
\hline [3] & 2 & 12 & 25 & 13 & 50 & 13.6 \\
\hline
\end{tabular}

The specific energies were calculated only from the three fuel gases listed in the table.

Table 3

Inputs and outputs parameters.

\begin{tabular}{|c|c|c|c|}
\hline Stream & Pressure (MPa) & Temperature $\left({ }^{\circ} \mathrm{C}\right)$ & Flowrate $\left(\mathrm{kg} \mathrm{s}^{-1}\right)$ \\
\hline Straw feed & 0.101 & 25 & 3.26 \\
\hline Slurry water & 0.101 & 25 & 4.57 \\
\hline Dryer/gasifier input & 2.050 & 213 & 10.46 \\
\hline Syngas product ex gasifier & 2.050 & 800 & 10.46 \\
\hline Steam turbine inlet & 6.000 & 320 & 16.00 \\
\hline Steam turbine outlet & 0.020 & 60 & 13.50 \\
\hline Passout steam & 2.050 & 320 & 2.50 \\
\hline Steam cycle feed water & 2.15 & 49 & 16.00 \\
\hline Syngas to gas turbine & 0.101 & 362 & 10.09 \\
\hline Air to gas turbine & 1.550 & 25 & 30.47 \\
\hline Gas turbine exhaust & 0.201 & 732 & 40.56 \\
\hline Stack gas & 0.101 & 138 & 63.48 \\
\hline
\end{tabular}

The tars are removed over a char bed by thermal treatment i.e. by the introduction a small bleed of air. Further gas cleaning is then carried out with hot with ceramic candle filters at temperatures between 350 and $370^{\circ} \mathrm{C}$, so that alkali salts would have condensed. Tests with bagasse indicate that most ash-forming components exit with the char from a cyclone gasifier, in contrast to the ash from a fluidised bed [49]. The literature suggests that tar concentrations of $50 \mathrm{mg} \mathrm{m}-3$ are acceptable for internal combustion engine applications, and higher levels for gas turbines [58].

The study by Kingwell and Abadi [14] of straw availability in the wheat belt of Western Australia established that a cost of $68 \$$ (in 2015) was appropriate for delivery to a centralised facility. Natural gas was costed at 7.5 \$ GJ-1. The char and ash removed from the gasifier were assumed to be returned to the farms as back-loading, to be spread onto the fields as soil improver, at a cost of $22 \$ \mathrm{t}-1$.

The application of spent gasifier solids to soil is subject to some reservations in view of the likely contamination with toxics. It appears that dioxins will not constitute a problem [58], nor will metals [59]. The main concern would be PAHs which could damage some soil microorganisms which promote plant growth. The proposed temperature of gasification $\left(800{ }^{\circ} \mathrm{C}\right)$ is above the $650{ }^{\circ} \mathrm{C}$ commonly used in the preparation of chars by pyrolysis only $[59,60]$, and the gasification simulation is carried out in the presence of steam, both of which will tend to destroy organic species.

Pricing the reactors was difficult, as it is an unusual configuration. The ECLIPSE package includes a 'tube bundle' reactor, which was adopted here in the form of 6 units. This figure was then doubled to allow for the complex tubing geometry.

The gas clean-up system was costed at $4 \%$ of the total capital cost. Prices were calculated in pounds Sterling, and then converted into US dollars (conversion used is $1.0 \$=£ 0.82$ in 2015). The operating costs were taken as $3 \%$ of the capital cost, maintenance $3 \%$ and an internal rate of return of $10 \%$ was adopted. The location in the WA wheat belt, although not remote, is sufficiently far from ports and manufacturing sites that an extra site premium of $20 \%$ was added. Although the ECLIPSE program is from the 1990s, the capital costs were updated using the CE index.

\section{Results}

The design of the process is operable when analysed on the ECLIPSE desktop simulation program. However, natural gas was needed to supply approximately $47 \%$ of the thermal input to the system. The composition of the syngas in Table 2 shows that as a consequence of the high $\mathrm{H} / \mathrm{O}$ ratio, the predominant gas is hydrogen. Table 2 also lists some experimental results from the literature for gas compositions obtained under similar, but lower pressure gasification conditions. The results obtained in the simulation are consistent with these data. As noted above, the amount of methane generated was arbitrarily decided, and may be conservative. However, the assumptions made are unlikely to modify the conclusions finally arrived at.

In this instance, water comprised $59 \%$ of the gas on a volume basis, and roughly the same on a mass basis. The higher specific energy of the dry syngas was $10.8 \mathrm{MJ} \mathrm{m}-3$ (measured at $298 \mathrm{~K}$ and $101.3 \mathrm{kPa}$ ), but only $4.30 \mathrm{MJ} \mathrm{m}-3$ wet. Although the water severely reduces the calorific value of the gas, it represents working fluid for the gas turbine and contributes to the overall output. The gas turbine generates $60 \%$ of the total electrical output, and the steam cycle $40 \%$.

The natural gas supplies 14.1 MWh to the gasifier in order to drive the endothermic reactions, and 19.1 MWh to the dryer. The net electrical output from the system is $29.5 \mathrm{MWe}$, with an overall electrical efficiency, considering both fuels, of $33.5 \%$. This is approximately $2 \%$ higher than the figure found for the pressurised gasification of straw under similar conditions [1], but is lower than what could be attained in a modern combined cycle gas turbine firing only natural gas. The decrease represents the penalty for introducing large amounts of liquid water into the process. Hence it represents a thermodynamic degradation of the natural gas, and would be contemplated only if the use of biomass was driving the application. The efficiency could be increased by using higher process conditions for both cycles. Natural gas was chosen here to give added thermal input to the process, but other alternatives such as coal or solar energy could be substituted. 
The emission of $\mathrm{SO}_{\mathrm{x}}$ is relatively modest at $285 \mathrm{mg} \mathrm{Nm}^{-3}$, but the high nitrogen content of the straw may require flue gas treatment, which would considerably increase the capital and operating costs of the plant. In the Australian context, this is unlikely as the installation would be at a comparatively isolated site.

In the NPV calculation a contingency of $15 \%$ was allowed, and the plant availability was taken as $85 \%$. The capital cost of the process calculated using the ECLIPSE software was $71.2 \mathrm{M} \$$ (in 2015). This was subsequently converted to US dollars i.e. 84 \$. As a result the unit capital cost of the plant is 2850 \$ kWe-1 When compared with recent literature values [61-63], this figure is found to be consistent with the lower-tech end of the reported values.

The production cost of power at zero NPV over 25 years was found to be $125 \$$ MWh-1, which is only slightly more than the 122 $\$$ figure calculated previously with the same software for conventional pressurised gasification [1]. However, in this case the technology is comprised of conventional-type equipment. It is also less than the estimate for the combustion/steam turbine route of 133 \$ MWh-1.

The proposed configuration lends itself to the application of solar energy as the auxiliary heating system, in order to decrease the use of natural gas. Two avenues present themselves. Firstly, a concentrated beam could be directed onto the array of cyclones through the aperture currently occupied by the gas burner. That burner could be repositioned as a ring of smaller radial burners. Thus make-up heat could be added when insolation is either not available, or is insufficient. Note that the size of gasifier unit discussed here requires over $2 \mathrm{MW}_{\text {th }}$ to sustain the reaction, and another $3+\mathrm{MW}_{\text {th }}$ for the evaporation/heating load. Secondly, the slurry preheating could easily be carried out in the tubes of trough solar concentrators.

\section{Conclusion}

The vexed question of using an aqueous slurry feed for pressurised gasification needs clarification, as it is extremely sensitive to the assumed water content. When an almost dry straw is converted into a $40 \%$ by volume slurry with water, a process simulation shows that auto-thermal gasification is untenable. An alternative process proposed here for gasifying wheat straw appears to be technically feasible and overcomes the limitations of conventional systems, but suffers from the penalty that a supplementary fuel such as natural gas needs to be employed at approximately the same thermal input. The efficiency of use of the natural gas is compromised in the system, due to the liquid water in the feed. The cost of power generation is competitive with classical BIGCC.

\section{References}

[1] B.R. Stanmore, A. Nzihou, Burn or gasify? An evaluation of biomass use for small-scale power generation, In preparation.

[2] A.V. Bridgwater, The technical and economic feasibility of biomass gasification for power generation, Fuel 14 (1995) 631-653.

[3] H.C. Hottel, J. Howard, New Energy Technology: Some Facts and Assessments, MIT Press, Cambridge, 1972. Mass 18.

[4] P.J. Woolcock, R.C. Brown, A review of cleaning technologies for biomassderived syngas, Biomass Bioenerg. 52 (2013) 54-84.

[5] P. Mondal, D.S. Dang, M.O. Garg, Syngas production through gasification and cleanup for downstream applications- recent developments, Fuel Proc. Tech. 92 (2011) 1395-1410.

[6] T.N. Trinh, P.A. Jensen, K. Dam-Johansen, N.O. Knudsen, H.R. Sørensen, P. Szabo, Properties of slurries made of fast pyrolysis oil and char or beech wood, Biomass Bioenerg. 61 (2014) 227-235.

[7] M. Sakaguchi, A.P. Watkinson, N. Ellis, Steam gasification of bio-oil and bio-oil/ char slurry in a fluidized bed reactor, Energy Fuels 24 (2010) 5181-5189.

[8] N. Dahmen, E. Henrich, E. Dinjus, F. Weirich, The bioliq ${ }^{\mathbb{B}}$ bioslurry gasification process for the production of biosynfuels, organic chemicals, and energy, Energy, Sustain. Soc. 2 (2012) 3-44.

[9] M. Zhang, S.B. Liaw, H. Wu, Bioslurry as a fuel. 5. Fuel properties evolution and aging during bioslurry storage, Energy Fuels 27 (2013) 7560-7568.
[10] M.L. de Souza-Santos, K.B. Ceribeli, Fuel-slurry integrated gasifier/gas turbine (FSIG/GT) alternative for power generation applied to Municipal Solid Waste (MSW), Energy Fuels 27 (2013) 7696-7713.

[11] M.L. de Souza-Santos, W.A. Beninca, New strategy of fuel-slurry integrated gasifier/gas turbine (FSIG/GT) alternative for power generation applied to biomass, Energy Fuels 28 (2014) 2697-2707.

[12] M.L. de Souza-Santos, Very high-pressure fuel-slurry integrated gasifier/gas turbine (FSIG/GT) power generation applied to biomass, Energy Fuels 29 (2015) 8066-8073.

[13] M.L. de Souza-Santos, New developments on fuel-slurry integrated gasifier gas turbine (FSIG/GT) alternative for power generation applied to biomass; configuration requiring No steam for gasification, Energy Fuels 29 (2015) 3879-3889.

[14] R. Kingwell, A. Abadi, Cereal straw for bioenergy production in an Australian region affected by climate change, Biomass Bioenergy 61 (2014) 58-65.

[15] K.R. Craig, M.K. Mann, Cost and Performance Analysis of Biomass-based Integrated Gasification Combined-cycle (BIGCC) Power Systems; NREL Report, Golden, NREL, CO, 1996.

[16] W. Hou, L. Zhang, J. Zhang, J. Bao, Rheology evolution and CFD modeling of lignocellulose biomass during extremely high solids content pretreatment, Biochem. Eng. J. 105 (Part B) (2016) 412-419.

[17] W.E. Mabee, P.N. McFarlane, J.N. Saddler, Biomass availability for lignocellulosic ethanol production, Biomass Bioenergy 35 (2011) 4519-4529.

[18] J. Stickel, J.S. Knutsen, M.W. Liberatore, et al., Rheology measurements of a biomass slurry: an inter-laboratory study, Rheol. Acta 48 (2009) 1005-1015.

[19] C.P.J. Bennington, R.J. Kerekes, J.R. Grace, The yield stress of fibre suspensions, Can. J. Chem. Eng. 68 (1990) 748-757.

[20] B.R. Stanmore, D.N. Page, Yield stresses and sedimentation in dense flyash slurries, Powder Technol. 72 (1992) 167-175.

[21] R. Chen, M. Wilson, Y.K. Leong, P. Bryant, H. Yang, D.K. Zhang, Preparation and rheology of biochar, lignite char and coal slurry fuels, Fuel 90 (2011) 1689.

[22] J.B. Kristensen, L.G. Thygesen, C. Felby, H. Jørgensen, T. Elder, Cell-wall structural changes in wheat straw pretreated for bioethanol production, Biotechnol. Biofuels 1 (2008) 5-14.

[23] P.S. Lam, S. Sokhansanj, X. Bi, S. Mani, C.J. Lim, A.R. Womac, M. Hoque, J. Peng, J. Shankar, J. Naimi, S. Nayaran, Physical Characterization of Wet and Dry Wheat Straw and Switchgrass - Bulk and Specific Density, 076058 ASABE Annual International Meeting, Minneapolis, Minnesota, 2007.

[24] G.G.D. Silva, S. Guilbert, X. Rouau, Successive centrifugal grinding and sieving of wheat straw, Powder Technol. 208 (2011) 266-270.

[25] G.G.D. Silva, M. Couturier, J.-G. Berrin, A. Buléon, X. Rouau, Effects of grinding processs on enzymatic degradation of wheat straw, Bioresour. Technol. 103 (2012) 192-200.

[26] S. Viamajala, J.D. McMillan, D.J. Schell, R.T. Elander, Rheology of corn stover slurries at high solids concentrations - effects of saccharification and particle size, Bioresour. Technol. 100 (2009) 925-934.

[27] G. Papachristodoulou, O. Trass, Coal slurry fuel technology, Can. J. Chem. Eng. 65 (1987) 177-201.

[28] M. Stahl, K. Granström, J. Berghel, R. Renström, Industrial processes for biomass drying and their effects on the quality properties of wood pellets, Biomass Bioenerg. 27 (2004) 621-628.

[29] A.S. Mujumdar, Superheated steam drying, in: A.S. Mujumdar (Ed.), Handbook of Industrial Drying, Marcel Dekker Inc, New York, 1995, pp. 195-233.

[30] Y. Komatsu, A. Sciazko, M. Zakrzewski, S. Kimijima, A. Hashimoto, S. Kaneko, J.S. Szmyd, An experimental investigation on the drying kinetics of a single coarse particle of Belchatow lignite in an atmospheric superheated steam condition, Fuel Proc. Tech. 131 (2015) 356-369.

[31] A. Tahmasebi, J. Yu, Y. Han, F. Yin, S. Bhattacharya, D. Stokie, Study of chemical structure changes of Chinese lignite upon drying in superheated steam microwave and hot air, Energy Fuels 26 (2012) 3651-3660.

[32] A.Y. Looi, K. Golonka, M. Rhodes, Drying kinetics of single porous particles in superheated steam under pressure, Chem. Eng. J. 87 (2002) 329-338.

[33] R. Jolly, Strawbale moisture monitoring report, 55 pages, Available from, baubiologie.at/download/CMHC.doc, December 1999.

[34] G.D. Bongers, W.R. Jackson, F. Woskoboenko, Pressurised steam drying of Australian low-rank coals Part 1. Equilibrium moisture contents, Fuel Proc. Technol. 57 (1998) 41-54.

[35] J. Berghel, R. Renström, Superheated steam drying of sawdust in continuous feed spouted beds - a design perspective, Biomass Bioenerg. 71 (2014) 228-234.

[36] A. Sattar, G.A. Leeke, A. Hornung, J. Wood, Steam gasification of rapeseed, wood, sewage sludge and miscanthus biochars for the production of a hydrogen-rich syngas, Biomass Bioenerg. 69 (2014) 276-286.

[37] M. Zhai, Y. Zhang, P. Dong, P. Liu, Characteristics of rice husk char gasification with steam, Fuel 158 (2015) 42-49.

[38] S.T. Chaudhari, S.K. Bej, N.N. Bakhshi, A.K. Dalai, Steam gasification of biomassderived char for the production of carbon monoxide-rich synthesis gas, Energy Fuels 15 (2001) 736-742.

[39] G. Maschio, A. Lucchesi, G. Stoppato, Production of syngas from biomass, Bioresour. Technol. 48 (1994) 119-126.

[40] C. Di Blasi, Modeling chemical and physical processes of wood and biomass pyrolysis, Prog. Energy Comb. Sci. 34 (2008) 47-90.

[41] W.-H. Chen, P.-C. Kuo, A study of torrefaction of various biomass materials and its impact on lignocellulosic structure simulated by a thermogravimetry, Energy 35 (2010) 2580-2586. 
[42] W-H. Chen, P.-C. Kuo, Torrefaction and co-torrefaction characterisation of hemicellulose, cellulose and lignin as well as torrefaction of some basic constituents in biomass, Energy 36 (2011) 801-811.

[43] M.J.C. Van der Stelt, H. Gerhauser, J.H.A. Kiel, K.J. Ptasinski, Biomass upgrading by torrefaction for the production of biofuels: a review, Biomass Bioenerg. 35 (2011) 3748-3762.

[44] J. Lédé, Comparison of contact and radiant ablative pyrolysis of biomass, J. Anal. Appl. Pyrolysis 70 (2003) 601-618.

[45] J. Lédé, The cyclone: a multifunctional reactor for the fast pyrolysis of biomass, Ind, Eng. Chem. Res. 39 (2000) 893-903.

[46] J. Lédé, F. Verzaro, B. Antoine, J. Villermaux, Flash pyrolysis of wood in a cyclone reactor, Chem. Eng. Proc. 20 (1986) 309-317.

[47] J. Lédé, J. Mercadier, Simulation of the thermocracking of biomass derived vapours, by the model reaction of decomposition of isocyanuric acid, J. Anal. Appl. Pyrolysis 67 (2003) 295-305.

[48] S. Sun, S. Zhao Sun, F. Zhao Ling, F. Su, Experimental research on air staged cyclone gasification of rice husk, Fuel Proc. Technol. 90 (2009) 465-471.

[49] M. Gabra, A. Nordin, M. Öhman, B. Kjellström, Alkali retention/separation during bagasse gasification: a comparison between a fluidised bed and a cyclone gasifier, Biomass Bioenerg. 21 (2001) 461-476.

[50] R. Saidur, E.A. Abdelaziz, A. Demirbas, M.S. Hossain, S. Mekhilef, A review on biomass as a fuel for boilers, Sustain Energy Rev. 15 (2011) 2262-2289.

[51] B.C. Williams, J.T. McMullan, Techno-economic analysis of fuel conversion and power generation systems - the development of a portable chemical process simulator with capital cost and economic performance analysis capabilities, Int. J. Energy Res. 20 (1996) 135-142.

[52] B.R. Stanmore, T. Dixon, P. Hobson, C. Spero, J. Pohl, Bagasse - a major renewable Queensland energy resource, First Int. Power Energy Conf, Churchill Vic, 1999, Paper 89.

[53] AP-40, EPA Air Pollution Engineering Manual, second ed., Environmental
Protection Agency, 1973.

[54] S. Heidenreich, P.U. Foscolo, New concepts in biomass gasification, Prog. Energy Combust. Sci. 46 (2015) 72-95.

[55] C. Dupont, G. Boissonet, J.-M. Seiler, P. Cauthier, D. Schweich, Study about the kinetic processes of biomass steam gasification, Fuel 86 (2007) 32-40.

[56] D. Ross, R. Noda, M. Horio, A. Kosminski, P. Ashman, P. Mullinger, Axial gas profiles in a bubbling fluidised bed biomass gasifier, Fuel 86 (2007) 1417-1429.

[57] H. Yu, Z. Zhang, Z. Li, D. Chen, Characteristics of tar formation during cellulose, hemicellulose and lignin gasification, Fuel 118 (2014) 250-256.

[58] S.E. Hale, J. Lehmann, D. Rutherford, Quantifying the total and bioavailable polycyclic aromatic hydrocarbons and dioxins in biochars, Environ. Sci. Technol. 46 (2012) 2830-2838.

[59] P. Oleszczuk, I. Jośko, M. Kuśmierz, Biochar properties regarding to contaminants content and ecotoxicological assessment, J. Hazard Mater 260 (2013) 375-382.

[60] M. Kołtowski, P. Oleszczuk, Toxicity of biochars after polycyclic aromatic hydrocarbons removal by thermal treatment, Ecol. Eng. 75 (2015) 79-85.

[61] US Energy Information Administration (EIA). Washongtion, DC20585: US Department of Energy, April 2013, Updated capital cost estimates for utility scale electricity generating plants, Available from: https://www.eia.gov/ forecasts/capitalcost/pdf/updated_capcost.pdf.

[62] D. Pauschert, Study of equipment prices in the power sector. The International Bank for Reconstruction and Development ESMAP Technical Paper 122/09, 2009.

[63] R. Tidball, J. Bluestein, N. Rodriguez, S. Knoke, Cost and Performance Assumptions for Modeling Electricity Generation Technologies, Subcontract Report NREL/SR-6A20-48595. Contract No. DE-AC36-08GO28308, November 2010. Available from, http://www.nrel.gov/docs/fy11osti/48595.pdf. 